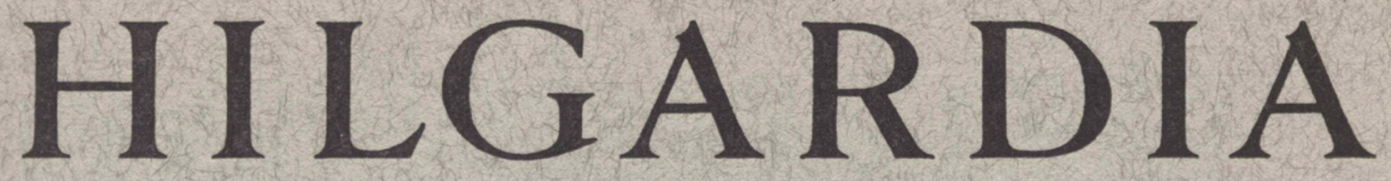

A Journal of Agricultural Science Publisbed by the California Agricultural Experiment Station

\title{
PHYTOTOXICITY OF HYDROCARBONS
}

H. B. CURRIER and S. A. PEOPLES 
Benzene, cyclohexene, cyclohexane, $\boldsymbol{n}$-hexane, and hexene-1 were applied to young carrot and barley plants as vapors diluted with air, and to Anacharis shoots and root and leaf segments of barley and carrot in aqueous solutions. The tetrazolium reaction and plasmolysis were employed as vitality criteria in the aqueous-solution tests.

With the vapors, toxicity (as the reciprocal of minimum lethal concentration) decreases in the order benzene, cyclohexene, cyclohexane, hexane, hexene.

Minimum lethal relative saturation in water increases in the order benzene, cyclohexene, cyclohexane, hexene, hexane; but on a molar concentration basis this order is reversed. In a general way the data appear to support the Ferguson Principle, that toxicity is related more to degree of saturation in a medium than to concentration. There seems to be no relation between water solubility and toxicity of low-boiling hydrocarbons of the types investigated.

Toxicity is closely related to oil-air distribution values, when plants are treated with hydrocarbon vapors, and when cottonseed and corn oils are used as models of cell lipid in calculating the distribution coefficients.

Calculation of theoretical concentration of hydrocarbon in cell lipid by use of distribution coefficients gives rather constant minimum lethal values of about 2 mols per liter for barley and 3 mols per liter for carrot tissue. Thus there seems to be no great difference in the absolute toxicity of the five substances; apparent differences must be ascribed to physical factors involved in movement of molecules to and retention at the site of physiological action.

The data obtained favor a mechanism of toxic action similar to that embraced by the classical Overton-Meyer theory of narcosis. The essence of this theory is that narcosis is brought about by accumulation of the narcotic in certain cell constituents, probably the lipids. All of the hydrocarbons studied are good lipid solvents. Used in sufficient amounts they act as cytolytics and are lethal to a marked degree. The site of action is probably the external limiting surface membrane of the cell, the ectoplast. This membrane is known to be rich in lipid; it is the first structure met upon absorption by the cell; and the rapid increase in permeability of cells is evidence that membrane structure has been altered. 


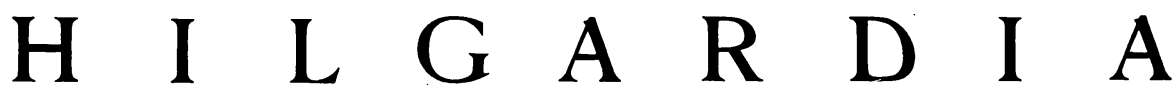

A Journal of Agricultural Science Published by

the California Agricultural Experiment Station

\section{PHYTOTOXICITY OF HYDROCARBONS}

\author{
H. B. CURRIER and S. A. PEOPLES
}

\section{INTRODUCTION}

Hydrocarbon oils are employed in the control of weeds, where the aim is complete elimination. They are used not only as toxicants, but also as carriers and cosolvents for other herbicides. On the other hand, oils find various horticultural applications-as carriers of insecticides and fungicides, for example-where it is important to minimize injury to the plant while providing adequate control of pests. To better accomplish these aims it is important to study the physiological effects of pure hydrocarbons on various plant functions, especially those processes involved in injury and death.

There is no agreement as to the mechanism of oil injury to plants. Literature reviews may be found in several publications (Crafts and Reiber, 1948; Minshall and Helson, 1949; Havis, 1950; Currier, 1951; Dallyn and Sweet, 1951).

There is evidence that hydrocarbons exert a solvent action on the external plasma membrane, the ectoplast, with resulting disorganization, increase of permeability, and leakage of cell sap into the intercellular spaces. This view was supported after studying the response of plants exposed to hydrocarbon vapors (Currier, 1951). That the plasma membrane is the critical structure in susceptibility and tolerance to oils is also the view of Dallyn and Sweet (1951), who arrived at this conclusion by use of quite different methods. The idea of "protoplasmic resistance" as a basis of selectivity of oils, as suggested by Crafts and Reiber (1948), has in general been substantiated by the more recent studies. However, it seems to be true that after oil is found within a cell severe injury or death invariably results (Dallyn and Sweet, 1951). This further stresses the importance of the protoplasmic surface.

Emphasis has been placed by some investigators on interference with normal progress of photosynthesis, respiration, and transpiration. Minshall and Helson (1949), on the basis of a careful series of measurements, concluded that petroleum naphtha caused a decrease in the rate of photosynthesis and transpiration, and changes in respiratory rate as well. There is

\footnotetext{
${ }^{1}$ Received for publication March 20, 1953.

${ }^{2} \mathrm{Mr}$. Currier is Associate Professor of Botany and Associate Botanist in the Experiment Station, Davis; Mr. Peoples is Professor of Comparative Pharmacology and Pharmacologist in the Experiment Station, Davis.
} 
no doubt but that such effects are associated with oil phytotoxicity, but it would seem that they aid in explaining slow-developing chronic injury more than rapid-acting acute injury. Spray oil injury to citrus, clearly chronic in nature, has been shown to be correlated with decreased photosynthetic and respiratory rates (Wedding, et al., 1952).

The retarding effect on respiratory activity of bean leaves by oxidized spray oils was studied by Johnson and Hoskins (1952). They found that acids and peroxides produced by laboratory oxidation at high temperature markedly increased the toxicity of highly refined spray oils containing almost entirely saturated aliphatic and naphthenic compounds. The lethal action of the oxidized oil was rapid and of the acute type. Tucker (1936) had previously associated chronic injury of spray oils with their acid content.

TABLE 1

CERTAIN PHYSICAL PROPERTIES OF HYDROCARBONS TESTED

\begin{tabular}{|c|c|c|c|c|c|c|}
\hline \multirow{2}{*}{ Hydrocarbon } & \multirow{2}{*}{$\begin{array}{l}\text { Molecular } \\
\text { weight }\end{array}$} & \multirow{2}{*}{$\begin{array}{l}\text { Density, } \\
\frac{20^{*}}{4}\end{array}$} & \multirow{2}{*}{$\begin{array}{l}\text { Boiling } \\
\text { point, } \\
{ }^{\circ} \mathrm{C} \dagger\end{array}$} & \multicolumn{2}{|c|}{$\begin{array}{l}\text { Vapor pressure, } \mathrm{mm} \mathrm{Hg} \\
\text { at } 25^{\circ} \mathrm{C}\end{array}$} & \multirow{2}{*}{$\begin{array}{c}\text { Water } \\
\text { solubility, } \\
\text { mols } / 1 \\
\text { solution, } \\
25^{\circ} \mathrm{C} \\
\text { (observed) }\end{array}$} \\
\hline & & & & Calculated & Observed & \\
\hline Benzene....... & 78.11 & 0.8794 & 80.1 & $94.6^{*}$ & 94.5 & 0.0237 \\
\hline Cyclohexene.. & 82.14 & .8102 & 83.2 & $\ldots \ldots$ & 87.0 & .0034 \\
\hline Cyclohexane... & 84.16 & .7791 & 80.8 & $98.9 \ddagger$ & 98.8 & .0013 \\
\hline Hexene-1...... & 84.16 & .6732 & 63.5 & $\ldots \ldots$ & 183.0 & .00092 \\
\hline$n$-Hexane. . & 86.17 & 0.6603 & 69.0 & $149.5^{*}$ & 151.0 & 0.00069 \\
\hline
\end{tabular}

* From Handbook of Chemistry and Physics (1950).

† From Timmermans (1950).

$\ddagger$ From Phillips Petroleum Co. (1949).

It may be pointed out here that in future work a clear distinction should be made between acute and chronic injury, and that pure compounds or oils of known composition must be employed, if interpretation of data is to have significance.

In an earlier study, the phytotoxicity of the series benzene, toluene, xylene, trimethylbenzenes was investigated by exposing plants to the hydrocarbon vapors dispersed in air (Currier, $1951^{3}$ ). These experiments permitted the conclusions: (1) that the type of injury produced is in each instance of the acute type rather than chronic; (2) that the hydrocarbons act more in a biophysical than in a biochemical manner; (3) that the plasma membrane is the critical structure affected; and (4) that the concentration range is very narrow, and partition phenomena determine concentration at point of action.

While the behavior of the four benzenes referred to suggests that they act nonspecifically in a more or less biophysical way, additional studies with respect to different types of hydrocarbons will help to establish relations between structure, physical properties, and phytotoxicity. This paper is the report of such a study.

${ }^{3}$ In this paper, concentrations in air of the hydrocarbons were erroneously reported too low by a factor of ten. 
Five hydrocarbons were chosen: $n$-hexane, hexene-1, cyclohexane, cyclohexene, and benzene. They were selected because all are 6-carbon compounds with similar molecular weights and exhibiting vapor pressures that are not too dissimilar (table 1), yet each represents a different type of hydrocarbon.

The investigations reported in this paper were in general of three kinds: (1) treatment of plants with hydrocarbon vapors diluted with air, (2) treatment with aqueous solutions of the hydrocarbons, and (3) determination of solubility and distribution phenomena, involving the phases air, water, and various oils.

\section{TREATMENT WITH VAPORS}

\section{Procedure}

For test plants, barley and carrot were used. Grown in cans in the greenhouse, barley was treated 2 weeks after planting, when the plants were in the two-leaf stage; carrots were 63 to 95 days from seed when treated. In certain tests designed to determine the effect of age on susceptibility, plants that varied more widely than the above were used.

The plants were treated in a simple gas chamber, described earlier (Currier, 1951). An air stream controlled by a flowmeter was passed through a vaporizing bottle containing the hydrocarbon, the level of which was kept constant by continuous addition through a burette. The concentration of vapor in the air stream was changed by varying the temperature of the water bath surrounding the vaporizing bottle. The operation was conducted in diffuse light in the greenhouse.

The variables in these experiments, in addition to species and age of test plants, were the following: (1) initially, with treatment time constant at 15 minutes, the concentration of hydrocarbon was varied; (2) with concentration constant, treatment time was varied from 30 minutes to 2 hours; (3) with concentration constant at a level not toxic in 2 hours, treatment time was extended to 8 hours; (4) finally, enough tests were run to establish the minimum concentration of each hydrocarbon giving 90 to 100 per cent injury in a 1-hour exposure.

Notes describing plant responses were recorded immediately after treatment, and after 24 hours, and 1, 2, and 4 weeks.

In the assessment of injury, assignment of values is based on the percentage of total leaf area killed. This is an approximation, but with carefully grown plants and with one individual making the judgments, consistent results can be obtained.

\section{Results}

Symptoms. The symptoms were those of acute injury, and have been described (deOng, Knight, and Chamberlin, 1927; Currier, 1951). No chronic injury (slow developing, systemic, long lasting) has been observed as an effect of any of the five hydrocarbons investigated.

${ }^{4}$ The $n$-hexane and hexene- 1 were supplied by the Phillips Petroleum Co., the cyclohexane by the Shell Development Co.; the cyclohexene was Eastman \#1043, and the benzene Baker's CP. 
First noticeable is the escape of foliage odor. This is definite, and it indicates an increase of permeability, at least with respect to these volatiles. Plants can release such odors and still fail to exhibit serious injury. As further evidence that an increase in permeability has occurred, very slight pressure on the leaf will darken it, owing to cell sap filling the intercellular

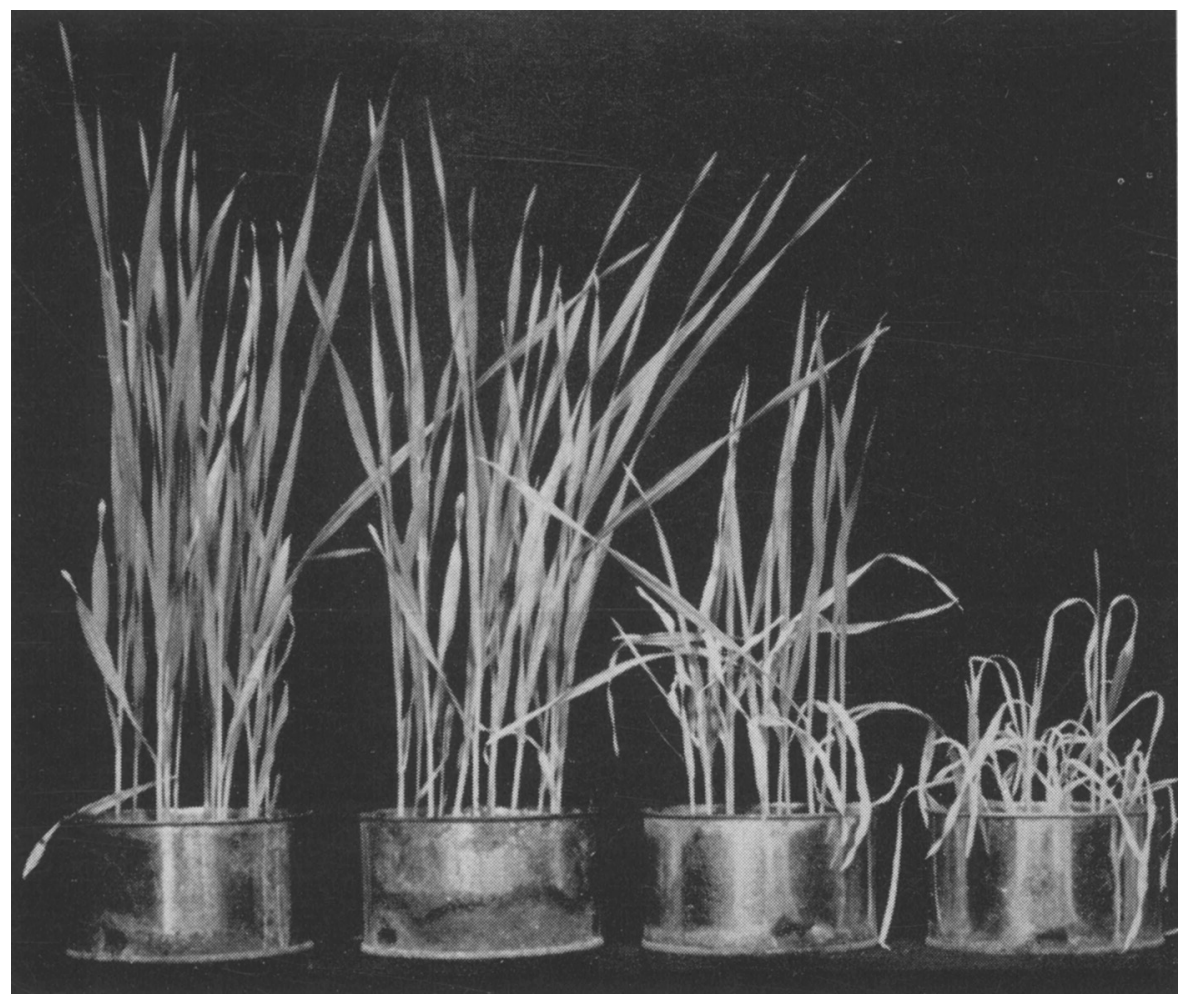

Fig. 1. Treatment of barley with hexene vapor, 15 minutes in each instance. Concentration from left to right: $0,4.3,7.1$, and $10.0 \mathrm{mM} / 1$ of air. Original injury $0,0,25$, and 95 per cent respectively. Photographed 10 days after treatment. Plants third from left are recovering.

spaces of the leaf. Considerably more pressure is required to produce the same effect on untreated leaves.

Next, dark areas appear in the leaves, followed by loss of turgor, complete wilting, and death.

Similarity of Action. The type of plant response to hexane, hexene, cyclohexane, cyclohexene, and benzene was the same in all treatments as far as visual judgment can be a basis. This is also the same response produced by vapors of toluene, xylene, and mesitylene.

Barley and Carrot Compared. Aside from the selectivity noted below, the two plants exhibited qualitatively identical injury symptoms, except that when leaves are killed, carrot almost invariably recovers by the development 
of new leaves from the crown; barley does not. Exceptions are that very young carrot plants did not resprout, and that young (5 day) barley sometimes continued to grow after all aerial growth had been killed. The latter response is apparently due to the protection provided the barley apical meristem at this stage of growth.

Selectivity. Carrots were more resistant than barley to all five hydrocarbons, under the conditions of the experiments (table 3). This indicates rather clearly that selective action is associated with the low-boiling hydrocarbons in weed-killing oils. It is known that the differential phytotoxicity, grasses versus carrots, is demonstrated in the field in connection with the acute type of injury (Crafts, Currier, and Leonard, 1951).

Age of Plants: As carrots grow older under greenhouse conditions they become somewhat more resistant to hydrocarbon vapors, as shown by tests with cyclohexane and cyclohexene. The degree of decreasing injury to 28 , 63,72 , and 126-day old plants was in the order of $95,85,75$, and 70 per cent, respectively, where injury was judged 24 hours after treatment. Similar tests on $5,7,12$, and 26-day-old plants of barley indicated that age within these limits is not an important factor, since the amount of injury was the same in all.

Order of Toxicity. A 15-minute treatment was found to be insufficient for equilibrium distribution of the hydrocarbon between the air and the plant; hence these data are not included in the tables. However, even with this brief exposure, all of the hydrocarbon vapors were definitely toxic. Figure 1 represents the response of barley to hexene vapors.

In all exposures the toxicity, on a molar basis, increased for both barley and carrot in the order hexene, hexane, cyclohexane, cyclohexene, benzene (tables 2,3). Toxicity is considered to bear a reciprocal relation to minimum lethal concentration. The two straight-chain hydrocarbons were considerably less toxic than the three cyclic compounds. There was little difference between hexene and hexane, but vapors of the latter were slightly more toxic. For example, $7.6 \mathrm{mM} / \mathrm{l}$ of hexene and $6.3 \mathrm{mM} / \mathrm{l}$ of hexane both produced 60 per cent injury in barley as a result of 15-minute treatments and 90 to 100 per cent after 60 minutes.

When sprayed on plants, the toxicity of pure hydrocarbons has been found to increase in the order straight-chain paraffins, olefins, naphthenes or cycloparaffins, aromatics (Crafts and Reiber, 1948; Havis, 1950; Leonard and Harris, 1952). In tests on carrots, Crafts and Reiber reported that cyclohexene and benzene were equally toxic, and that these were somewhat more so than cyclohexane; $n$-hexane was much less toxic. The studies reported in this paper indicate a similar order of toxicity when hydrocarbon vapors are used instead of liquids. Employing a larger assortment of hydrocarbons, Ivens (1952) noted that some, not toxic in the vapor phase, were extremely toxic as liquids. Lack of toxicity was explained by a low vapor pressure.

Time and Concentration. There is no simple time-concentration relation in acute hydrocarbon toxicity. The behavior of plants treated for 15 minutes indicated that the reaction is quite rapid when the concentration is at a lethal level. While there was usually increased injury when the treatment 
TABLE 2

PER CENT INJURY TO BARLEY AND CARROT PLANTS FOLLOWING ONE-HALF TO TWO-HOUR TREATMENT WITH HYDROCARBONS

\begin{tabular}{|c|c|c|c|c|c|c|}
\hline \multirow[b]{2}{*}{ Hydrocarbon } & \multirow{2}{*}{$\begin{array}{l}\text { Concentra- } \\
\text { tion, mM/l } \\
\text { air mixture }\end{array}$} & \multirow[b]{2}{*}{ Plant } & \multirow{2}{*}{$\begin{array}{l}\text { Days after } \\
\text { treatment }\end{array}$} & \multicolumn{3}{|c|}{ Per cent injury with: } \\
\hline & & & & $\begin{array}{l}1 / 2 \text {-hour } \\
\text { treatment }\end{array}$ & $\begin{array}{l}1 \text {-hour } \\
\text { treatment }\end{array}$ & $\underset{\text { treatment }}{2 \text {-hour }}$ \\
\hline \multirow[t]{2}{*}{ Hexane } & 4.5 & Barley $\ldots \ldots \ldots, \ldots, \ldots$ & $\left\{\begin{array}{r}1 \\
14 \\
28\end{array}\right.$ & $\begin{array}{l}0 \\
0 \\
0\end{array}$ & $\begin{array}{l}5 \\
5 \\
0\end{array}$ & $\begin{array}{l}\mathbf{5} \\
\mathbf{5} \\
\mathbf{0}\end{array}$ \\
\hline & 4.5 & Carrot.................. & $\left\{\begin{array}{r}1 \\
14 \\
28\end{array}\right.$ & $\begin{array}{l}0 \\
0 \\
0\end{array}$ & $\begin{array}{l}0 \\
0 \\
0\end{array}$ & $\begin{array}{l}\mathbf{0} \\
0 \\
0\end{array}$ \\
\hline \multirow{2}{*}{ Hexene } & 4.6 & Barley...$\ldots \ldots \ldots \ldots$ & $\left\{\begin{array}{r}1 \\
14 \\
28\end{array}\right.$ & $\begin{array}{l}0 \\
0 \\
0\end{array}$ & $\begin{array}{l}5 \\
5 \\
0\end{array}$ & $\begin{array}{l}5 \\
5 \\
0\end{array}$ \\
\hline & 4.6 & Carrot................. & $\begin{array}{r}1 \\
14 \\
28\end{array}$ & $\begin{array}{l}0 \\
0 \\
0\end{array}$ & $\begin{array}{l}0 \\
0 \\
0\end{array}$ & $\begin{array}{l}0 \\
0 \\
0\end{array}$ \\
\hline \multirow{2}{*}{ Cyclohexane } & 2.8 & Barley....... & $\left\{\begin{array}{r}1 \\
14 \\
28\end{array}\right.$ & $\begin{array}{r}10 \\
95 \\
100\end{array}$ & $\begin{array}{r}15 \\
98 \\
100\end{array}$ & $\begin{array}{l}25 \\
85 \\
85\end{array}$ \\
\hline & 4.2 & Carrot........ & $\begin{array}{r}1 \\
14 \\
28\end{array}$ & $\begin{array}{l}10 \\
25 \\
25\end{array}$ & $\begin{array}{l}15 \\
25 \\
25\end{array}$ & $\begin{array}{l}25 \\
30 \\
35\end{array}$ \\
\hline \multirow{2}{*}{ Cyclohexene } & 2.8 & Barley.... & $\left\{\begin{array}{r}1 \\
14 \\
28\end{array}\right.$ & $\begin{array}{r}95 \\
100 \\
100\end{array}$ & $\begin{array}{r}95 \\
100 \\
100\end{array}$ & $\begin{array}{r}95 \\
100 \\
100\end{array}$ \\
\hline & 4.2 & Carrot........ & $\begin{array}{r}1 \\
14 \\
28\end{array}$ & $\begin{array}{l}90 \\
60 \\
25\end{array}$ & $\begin{array}{l}95 \\
85 \\
30\end{array}$ & $\begin{array}{l}95 \\
80 \\
25\end{array}$ \\
\hline \multirow{3}{*}{ Benzene } & 2.7 & Barley ............... & $\left\{\begin{array}{r}1 \\
14 \\
28\end{array}\right.$ & $\begin{array}{l}85 \\
95 \\
95\end{array}$ & $\begin{array}{r}90 \\
100 \\
100\end{array}$ & $\begin{array}{r}95 \\
100 \\
100\end{array}$ \\
\hline & 2.7 & Carrot................ & $\left\{\begin{array}{r}1 \\
14 \\
28\end{array}\right.$ & $\begin{array}{l}0 \\
0 \\
0\end{array}$ & $\begin{array}{l}0 \\
0 \\
0\end{array}$ & $\begin{array}{l}0 \\
0 \\
0\end{array}$ \\
\hline & 3.0 & Carrot................ & 1 & 10 & 10 & 10 \\
\hline
\end{tabular}

time was extended from $1 / 2$ hour to 1 and 2 hours, the differences were not great, and beyond 2 hours, time seems an even smaller factor. As further evidence, when an 8-hour exposure to a concentration just below that which is lethal in 1 hour was given, there was either no injury or it was slight (table 4). For experimental purposes 1 hour is a convenient and satisfactory treatment period. 


\section{TREATMENT WITH AQUEOUS SOLUTIONS OF HYDROCARBONS}

Toxicity studies have shown that for many plant tissues visual judgment of vitality based on apparent necrosis is not a satisfactory criterion. Plasmolysis is generally infallible (Currier, 1949), but this method is tedious.

TABLE 3

CONCENTRATION IN AIR OF HYDROCARBON FOUND

TO PRODUCE $90-100 \%$ INJURY IN A

ONE-HOUR TREATMENT

Judgments made 24 hours later

\begin{tabular}{|c|c|c|}
\hline \multirow{2}{*}{ Hydrocarbon } & \multicolumn{2}{|c|}{ Concentration in air, $\mathrm{mM} / \mathrm{l}$} \\
\hline & $\begin{array}{c}\text { With } \\
\text { barley }\end{array}$ & $\begin{array}{l}\text { With } \\
\text { carrot }\end{array}$ \\
\hline Benzene......... & 2.6 & 3.9 \\
\hline Cyclohexene............ & 2.7 & 4.2 \\
\hline Cyclohexane $\ldots \ldots \ldots, \ldots, \ldots, \ldots, \ldots, \ldots, \ldots, \ldots$ & 3.9 & 5.4 \\
\hline 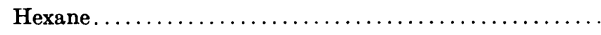 & 6.3 & 7.8 \\
\hline 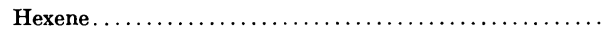 & 7.6 & 9.7 \\
\hline
\end{tabular}

TABLE 4

INJURY TO BARLEY AND CARROT WITH LONGER EXPOSURES TO HYDROCARBON VAPORS

\begin{tabular}{|c|c|c|c|c|c|c|}
\hline \multirow{2}{*}{ Plant } & \multirow{2}{*}{ Hydrocarbon } & \multirow{2}{*}{$\begin{array}{c}\text { Concentration, } \\
\mathrm{mM} / 1 \\
\text { of air mixture }\end{array}$} & \multirow{2}{*}{$\begin{array}{l}\text { Time after } \\
\text { treatment }\end{array}$} & \multicolumn{3}{|c|}{ Per cent injury with: } \\
\hline & & & & $\begin{array}{l}\text { 2-hour } \\
\text { treatment }\end{array}$ & $\begin{array}{c}\text { 4-hour } \\
\text { treatment }\end{array}$ & $\begin{array}{c}\text { 8-hour } \\
\text { treatment }\end{array}$ \\
\hline Barley & Benzene & 1.2 & $\begin{array}{l}1 \text { day } \\
2 \text { weeks } \\
4 \text { weeks }\end{array}$ & $\begin{array}{l}0 \\
0 \\
0\end{array}$ & $\begin{array}{l}0 \\
0 \\
0\end{array}$ & $\begin{array}{l}\text { Trace } \\
\text { Trace } \\
\text { Trace }\end{array}$ \\
\hline Barley & Cyclohexane & 2.3 & $\begin{array}{l}1 \text { day } \\
2 \text { weeks } \\
4 \text { weeks }\end{array}$ & $\begin{array}{l}0 \\
0 \\
0\end{array}$ & $\begin{array}{l}5 \\
0 \\
0\end{array}$ & $\begin{array}{r}10 \\
0 \\
0\end{array}$ \\
\hline Carrot & Cyclohexene & 1.7 & $\begin{array}{l}1 \text { day } \\
2 \text { weeks } \\
4 \text { weeks }\end{array}$ & $\begin{array}{l}0 \\
0 \\
0\end{array}$ & $\begin{array}{l}0 \\
0 \\
0\end{array}$ & $\begin{array}{l}0 \\
0 \\
0\end{array}$ \\
\hline Barley & Cyclohexene & 1.7 & 1 day & 10 & 20 & 30 \\
\hline
\end{tabular}

Application of the tetrazolium reaction to biological problems (cf. Smith, 1951 ) is a distinct contribution. Living tissues absorb and reduce the colorless dye to a red formazan. Dehydrogenases are believed responsible for the reduction (Jensen, Sacks, and Baldauski, 1951).

Comparative tests (unpublished) of the tetrazolium reaction and plasmolysis, using Anacharis as test material, indicate good agreement between the two methods of distinguishing living from dead cells. In applying the method to Anacharis, and to the leaf and root segments tested, a 0.05 per cent solution of 2,3,5 triphenyltetrazolium chloride in local tap water ( $\mathrm{pH} 7.8$ ) was 
employed. There was adequate color development after 16 to 24 hours in the dark at $25^{\circ} \mathrm{C}$, and the toxicity was low enough to permit cells to remain alive after this period. Cells of both control and treated plants containing considerable formazan deposits remained plasmolyzable.

\section{Tests on Anacharis}

Anacharis canadensis (elodea) material was available from greenhouse culture tanks, where the plants grow in tap water the year round. A submerged aquatic, it is suitable for studies with aqueous solutions. Shoot seg-

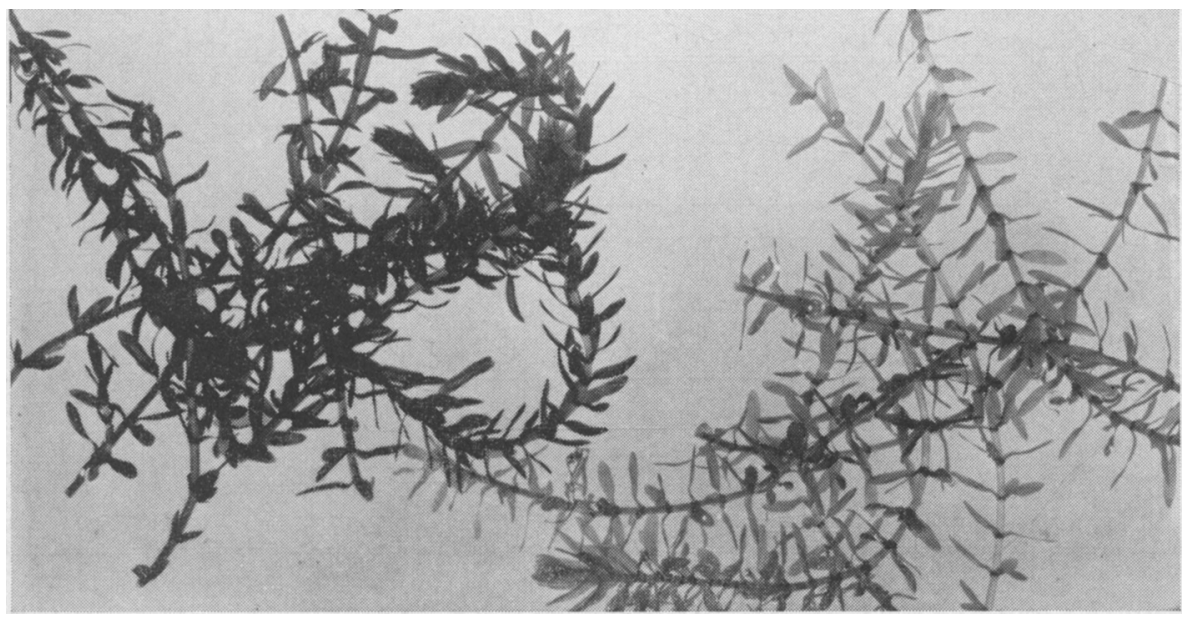

Fig. 2. The tetrazolium reaction in Anacharis shoots. Left, treated with tetrazolium (red in color); right, untreated (normal green).

ments $2 \frac{1}{2}$ inches long, in replicates of four, were treated for 1 hour with aqueous solutions of the hydrocarbons in capped Mason jars mounted on a rocking-type agitator. The temperature was controlled at $25^{\circ} \mathrm{C}$ and light intensity at 200 foot-candles.

Saturated solutions were prepared by gently agitating tap water in contact with an excess of hydrocarbon liquid, at $25^{\circ} \mathrm{C}$. Dilutions were subsequently made by addition of tap water, and concentrations were calculated from the saturation value.

$\Lambda$ fter treatment with the hydrocarbons in aqueous solution the shoots were placed in 0.05 per cent tetrazolium chloride solution. After 24 hours in the dark, living shoots were red, dead shoots normal green. The difference between the concentration which permitted the tissues to remain alive (as judged by their red color) and that which killed was surprisingly small. Figure 2 compares treated and untreated shoots of Anacharis.

In a preliminary experiment, saturated solutions of all the hydrocarbons except hexane killed quickly, at least within 1 hour. Hexane-treated shoots showed no significant injury after 20 hours of exposure to the solution.

Next half-saturated solutions were used, with the result that benzene and cyclohexene killed in 1 hour, hexene and cyclohexane did not. Subsequent 
trials of graded solutions in steps of 0.05 per cent saturation gave the results shown in table 5 . These minimum lethal concentrations were confirmed by another procedure in which fresh solution constantly flowed into the treatment vessel.

On a per cent saturation basis, the increasing toxicity series is hexane, hexene, cyclohexane, cyclohexene, benzene. However, on a concentration basis the order is just the reverse. This matter is considered further in a later section.

\section{Tests on Leaves and Roots}

Greenhouse-grown barley and carrot plants were employed. One-inch segments were cut from the second leaf of 14-day-old barley plants, using the

TABLE 5

AMOUNTS OF HYDROCARBON KILLING ANACHARIS
IN ONE HOUR AT $25^{\circ} \mathrm{C}$

Expressed as relative saturation (complete saturation $=1.0$ ) and millimols per liter of water

\begin{tabular}{|c|c|c|}
\hline Hydrocarbon & $\begin{array}{l}\text { Relative } \\
\text { saturation }\end{array}$ & $\mathrm{m} M$ per 1 \\
\hline Benzene............. & 0.40 & 9.48 \\
\hline Cyclohexene............... & 0.45 & 1.53 \\
\hline Cyclohexane ....................... & 0.80 & 1.07 \\
\hline 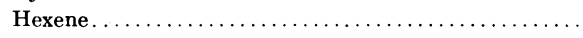 & 0.90 & 0.83 \\
\hline Hexane.$\ldots \ldots \ldots \ldots \ldots \ldots \ldots \ldots \ldots \ldots \ldots \ldots \ldots \ldots \ldots \ldots \ldots$ & 1.0 not lethal & $>0.69$ \\
\hline
\end{tabular}

middle two thirds of the leaf. Duplicates were treated in capped Mason jars with aqueous solutions of the various hydrocarbons, varying in steps of 0.1 of saturation at $25^{\circ} \mathrm{C}$, or sometimes in steps of 0.05 . Terminal $11 / 2$-inch segments of main barley roots, carrot leaflets, and thin (500 micron) sections of $1 / 2$-inch diameter carrot roots were also treated. The leaf segments were weighted to keep them from collecting at the top; the root sections did not require this.

After 8 hours at $25^{\circ} \mathrm{C}$ and 200 foot-candles of light, the sections were transferred directly to 0.05 per cent tetrazolium chloride solutions. The leaf segments gave a rather poor response to the dye, but loss of turgor and darkening were additional criteria of death. Carrot root slices gave quite positive results, but barley-root behavior was difficult to interpret. Plasmolysis tests aided in establishing minimum lethal concentrations. The tetrazolium reaction in barley root was most pronounced in the stele, but was also observed in cortical parenchyma and in the apical meristem, the cells of which seemed to be the most resistant of all in the root to the hydrocarbons. A solution was considered lethal if it killed all cells except possibly these meristematic cells.

The minimum lethal concentrations determined for the five hydrocarbons, under the conditions of the experiment, are shown in table 6. Barley leaf behaved very much as did Anacharis. Carrot leaf was considerably more resistant. It is of interest that with benzene the root segments remained alive in concentrations that were lethal for leaves. Several supplementary 
tests of benzene solutions on radish, turnip, parsnip, and celery, indicated that the first two were the more susceptible, and that roots in each instance were more resistant than leaves. However, this relation was not shown in the effect of the other four hydrocarbons on barley and carrot (table 6).

TABLE 6

MINIMUM AMOUNTS OF HYDROCARBONS IN AQUEOUS SOLUTION LETHAL TO BARLEY AND CARROT LEAF AND ROOT SECTIONS IN AN 8-HOUR EXPOSURE AT $25^{\circ} \mathrm{C}$

Expressed as concentration in millimols per liter and as relative saturation $(100$ per cent $=1)$

\begin{tabular}{|c|c|c|c|c|c|c|c|c|}
\hline \multirow[b]{2}{*}{ Hydrocarbon } & \multicolumn{4}{|c|}{ Concentration, $\mathrm{mM} / \mathrm{l}$} & \multicolumn{4}{|c|}{ Relative saturation } \\
\hline & $\begin{array}{c}\text { With } \\
\text { barley } \\
\text { leaf }\end{array}$ & $\begin{array}{c}\text { With } \\
\text { carrot } \\
\text { leaf }\end{array}$ & $\begin{array}{c}\text { With } \\
\text { barley } \\
\text { root }\end{array}$ & $\begin{array}{l}\text { With } \\
\text { carrot } \\
\text { root }\end{array}$ & $\begin{array}{c}\text { With } \\
\text { barley } \\
\text { leaf }\end{array}$ & $\begin{array}{l}\text { With } \\
\text { carrot } \\
\text { leaf }\end{array}$ & $\begin{array}{c}\text { With } \\
\text { barley } \\
\text { root }\end{array}$ & $\begin{array}{c}\text { With } \\
\text { carrot } \\
\text { root }\end{array}$ \\
\hline Benzene..... & 8.3 & 14.2 & 11.9 & 21.3 & 0.35 & 0.60 & 0.50 & 0.90 \\
\hline Cyclohexene... & 1.4 & 2.4 & 1.4 & 2.4 & 0.40 & 0.70 & 0.40 & 0.70 \\
\hline Cyclohexane.... & 0.91 & $\ldots{ }^{*}$ & 0.91 & $\ldots *^{*}$ & 0.70 & $>1.0^{*}$ & 0.70 & $>1.0^{*}$ \\
\hline Hexene............. & 0.73 & $\ldots{ }^{*}$ & 0.73 & $\ldots{ }^{*}$ & 0.80 & $>1.0^{*}$ & 0.80 & $>1.0^{*}$ \\
\hline Hexane............ & $\ldots{ }^{*}$ & $\ldots{ }^{*}$ & 0.69 & $\ldots{ }^{*}$ & $>1.0^{*}$ & $>1.0^{*}$ & 1.0 & $>1.0^{*}$ \\
\hline
\end{tabular}

* Not lethal in saturated solution.

TABLE 7

DISTRIBUTION COEFFICIENTS AT $25^{\circ} \mathrm{C}$

\begin{tabular}{|c|c|c|c|c|c|c|}
\hline \multirow{2}{*}{ Hydrocarbon } & \multicolumn{2}{|c|}{$\frac{\text { Water }}{\text { Air }}$} & \multicolumn{2}{|c|}{$\frac{\mathrm{Oil}^{*}}{\mathrm{Air}}$} & \multicolumn{2}{|c|}{$\frac{\text { Oil }^{*}}{\text { Water }}$} \\
\hline & $\mathrm{mols} / \mathrm{l}$ & $K$ & $\mathrm{mols} / \mathrm{l}$ & $K$ & $\mathrm{mols} / \mathrm{l}$ & $K$ \\
\hline Benzene...... & $\frac{0.0237}{0.0051}$ & 4.65 & $\frac{4.88}{0.0051}$ & 960 & $\frac{4.88}{0.0237}$ & 206 \\
\hline Cyclohexene. . & $\frac{0.0034}{0.0047}$ & 0.72 & $\frac{4.26}{0.0047}$ & 911 & $\frac{4.26}{0.0034}$ & 1,270 \\
\hline Cyclohexane. & $\frac{0.0013}{0.0053}$ & 0.25 & $\frac{2.97}{0.0053}$ & 560 & $\frac{2.97}{0.0013}$ & 2,210 \\
\hline Hexene......... & $\frac{0.00092}{0.0099}$ & 0.093 & $\frac{2.80}{0.0099}$ & 283 & $\frac{2.80}{0.00092}$ & 3,040 \\
\hline Hexane.. & $\frac{0.00069}{0.0082}$ & 0.085 & $\frac{2.49}{0.0082}$ & 305 & $\frac{2.49}{0.00069}$ & 3,590 \\
\hline
\end{tabular}

* Cottonseed oil.

Greater resistance of roots to hydrocarbons than of leaves would be in agreement with the idea that the root is adapted to absorption of polar substances, the leaf to nonpolar substances (Crafts, 1948). Perhaps it could be said that the root is simply more polar than the leaf, and it is not improbable that the plasma membranes of root cells are more hydrophilic than those of leaf cells, and consequently absorb relatively less hydrocarbon. 
Further importance in these results may be noted in the fact that isolated sections of carrot root and leaf appear to show the same relative resistance to hydocarbons as do intact plants. Thus the individual cell is probably the important entity in this type of toxicity and selectivity, rather than whole plants or organs.

\section{DETERMINATION OF PHYSICAL CONSTANTS}

Solubility phenomena are considered the most important physical properties of the hydrocarbons in this investigation. In addition to solubility in air, water, and oil, interesting relations are shown by equilibrium distribution of hydrocarbon between the systems water-air, oil-air, and oil-water. All may be calculated on the basis of vapor-pressure measurements using a Van Slyke manometric blood gas apparatus. The method in general is an adaptation of that outlined by Van Slyke (1939). Improvements and details of technique will appear elsewhere. ${ }^{5}$

Concentration of hydrocarbon in air is a direct function of its partial pressure, according to Dalton's Law. Knowing volume of flask, volume of liquid, and concentration of hydrocarbon in liquid, Henry's Law may be employed to calculate the water/air distribution ratio at any concentration. This law may be stated:

$$
m=P k_{\mathrm{w}}
$$

where $P=$ partial pressure of hydrocarbon vapor in equilibrium with hydrocarbon dissolved in the liquid, $k_{\mathrm{w}}=$ Henry's Law constant, $m=$ mols of hydrocarbon per liter of water. Mols per liter of air $=\frac{n}{V}=\frac{P}{R T}$, where $n=$ number of mols of hydrocarbon vapor, $V=$ volume in liters, $R=$ gas constant in the relation $P V=n R T$, and $T$ is absolute temperature.

The water/air distribution coefficient then is equal to:

$$
K_{\mathrm{w} / \mathrm{a}}=\frac{\text { mols per liter in water }}{\text { mols per liter in air }}=\frac{P k_{\mathrm{w}}}{P / R T}=k_{\mathrm{w}} R T .
$$

Oil/air distribution constants may be similarly calculated:

$$
\begin{gathered}
m=P k_{\mathrm{o}}, \text { where } k_{\mathrm{o}}=\text { Henry's Law constant for oil. } \\
K_{\mathrm{o} / \mathrm{a}}=\frac{\text { mols per liter in oil }}{\text { mols per liter in air }}=\frac{P k_{\mathrm{o}}}{P / R T}=k_{\mathrm{o}} R T .
\end{gathered}
$$

Finally, oil/water distribution coefficients may be obtained:

$$
K_{\mathrm{o} / \mathrm{w}}=\frac{K_{\mathrm{o} / \mathrm{a}}}{K_{\mathrm{w} / \mathrm{a}}}=\frac{k_{\mathrm{o}} R T}{k_{\mathrm{w}} R T}=\frac{k_{\mathrm{o}}}{k_{\mathrm{w}}}
$$

The above calculations and measurements assume ideal behavior of solutions of hydrocarbons. This is believed to be a valid assumption for nonpolar substances of low water solubility.

Values obtained by these procedures are shown in table 7 , where cottonseed oil (Wesson oil) served as the model. The use of corn oil (Mazola) led to quite similar values, but paraffin oil (Standard No. 3 White) gave values which were not of the same order (table 8 ).

\footnotetext{
${ }^{5}$ Peoples, S. A. Unpublished data, 1953.
} 


\section{DISCUSSION AND CONCLUSIONS}

\section{Mechanism of Toxicity}

Low-boiling hydrocarbons such as benzene are narcotic substances, characterized by their ability to depress certain cellular functions. Used in sufficient amount, they become markedly toxic and act as cytolytics to disrupt cellular organization. When they are employed as herbicides this disruption apparently occurs first at the ectoplast, the external protoplast surface, resulting in a pathological and irreversible increase in permeability.

The protoplast surface may be viewed as a lipid-hydrated protein complex a few molecules thick (see, for example, Davson and Danielli, 1952), the structure of which must be maintained by a continuous expenditure of

TABLE 8

DISTRIBUTION COEFFICIENTS WHERE CORN AND PARAFFIN OILS WERE USED AS MODELS

\begin{tabular}{|c|c|c|c|c|}
\hline \multirow{2}{*}{ Hydrocarbon } & \multicolumn{2}{|c|}{ Corn oil } & \multicolumn{2}{|c|}{ Paraffin oil } \\
\hline & Oil/air & Oil/water & Oil/air & Oil/water \\
\hline Benzene..... & 850 & 183 & 607 & 131 \\
\hline Cyclohexene........... & 736 & 1,020 & 780 & 1,080 \\
\hline Cyclohexane............ & 542 & 2,170 & 853 & 3,410 \\
\hline Hexene............. & 286 & 3,080 & 350 & 3,760 \\
\hline Hexane.............. & 272 & 2,930 & 368 & 3,960 \\
\hline
\end{tabular}

energy. The lipids may be predominantly phospholipids. In the most elementary view, a hydrocarbon such as benzene becomes adsorbed on or dissolved in the lipid phase and disrupts the supposedly intimate bonds between the protein and fatty components of the surface membrane. As the concentration of hydrocarbon increases, there is a point where the membrane becomes so permeable that the cell contents leak out.

It is of course illogical to consider that a substance acts wholly in a physical or wholly in a chemical way, because ultimately the same forces are involved. This is especially true with reference to the plasma membrane, a living structure that is maintained by chemical reactivity. But without any strict distinction, it is advantageous to separate certain toxicants which may be considered nonspecific, or indifferent, remaining unchanged in the process, from other substances which are toxic because they enter directly into biochemical reactions (Ferguson, 1939; Albert, 1951; Danielli, 1950).

The herbicidal activity of hydrocarbons, at least the low-boiling type dealt with in the present report, must depend on the same mechanism and factors as those operating in the Overton-Meyer lipid solubility theory of narcosis (Overton, 1901), which was later amplified and extended by Meyer and Hemmi (1935). Overton showed the strength of certain indifferent substances to lie in the same order as their oil/water partition coefficients. The employment of this theory in studying herbicidal mechanisms may help to solve some of the problems associated with the penetration of many different kinds of substances, herbicides and others, into leaves and roots. While the same principles may be operating as in animals, the reaction in plants is 
different in some respects. Lack of a specialized nervous system permits focusing of attention more on the individual cell. Presence of intercellular air spaces makes possible the detection of leakage from cells.

The idea that cell lipids constitute the critical phase in which hydrocarbons and other indifferent substances exert their action agrees well with experimental facts (Meyer and Hemmi, 1935). Under the present circumstances the critical lipid structure seems to be that of the protoplasmic surface. This is based on the observation that darkening of the leaf is the first visible response in the gas chamber, and that sublethal concentrations do not seem to cause injury. Chloroplasts are high in lipid, yet it seems that they do not suffer injury while the plasma membrane remains intact.

The structure of the plasma membrane is unknown, but there are many theories concerning it. The lipid phase may be homogeneous or nonhomogeneous; it may consist of orientated apolar chains of proteins as well as phospholipids. Use of a seed oil as a model assumes that the lipid of the membrane may have similar solvent properties toward hydrocarbons. The present data suggest that this might be true. One would think that the assumed definite orientation of lipid molecules in the membrane would result in different solvent power as compared with random arrangement in bulk. The first stage of accumulation of hydrocarbon at the protoplast exterior is doubtless an adsorption process, but from this initial point to the lethal concentration it is not known whether adsorptive forces bringing about accumulation at surfaces can be distinguished from solution forces. Distribution coefficient values were calculated on the basis of solution equilibria, and it is simpler at this stage of knowledge to consider that hydrocarbon "dissolves" in the lipid portion of the membrane.

As many have pointed out, a positive correlation between narcotic strength and lipid solubility does not constitute a mechanism, but only suggests that a lipid phase in the cell may be the site of action. While the evidence points to increased permeability as the toxic mechanism, underlying this change must be submicroscopic changes in membrane structure. As to these, some rather specific suggestions have been made, a discussion of which may be found in a review by Butler (1950).

Van Overbeek and Blondeau (1953) have developed the most complete picture of hydrocarbon phytotoxicity at the molecular level yet proposed. Solubilization, the incorporation of foreign molecules in the colloidal micelles of surface-active substances, plays an important role. Hydrocarbon molecules are considered to solubilize in the lipid portions of the plasma membrane and thus "open up" this surface, which results in leakage of cell contents and death. These workers suggest that chronic oil injury, in addition to acute injury, is explainable as a solubilization phenomenon, except that in chronic injury a different time factor is involved.

Any disruption of energy supply would affect permeability, and this could be due to the presence of the foreign molecules themselves at the surface, or to their accumulation in regions of the interior protoplasm that are intimately associated with energy metabolism. More definite conclusions as to what is precisely happening at the surface will come with better understanding of its structure and function. 
There is a lack of information as to the extent to which higher plants can metabolize hydrocarbons, with the production of acids and peroxides. But while enzymatic or other oxidation occurring within the plant may be an important aspect of chronic oil injury, it is less likely that this is true of acute injury, and particularly with reference to the compounds dealt with here. Further investigations are desirable to determine to what extent permeability factors are involved in chronic toxicity, and also in the quite rapid killing by highly acidic oils (Johnson and Hoskins, 1952).

\section{Relation of Various Physical Factors to Toxicity}

Molecular Structure. From studies made to correlate toxicity of narcoticlike hydrocarbons with molecular structure, one concludes that structure is important only as it determines certain physical properties (Ferguson, 1939 ; Albert, 1951 ; Danielli, 1950). Ivens (1952), determining toxicity of eighteen kinds of hydrocarbon vapors, concluded that it is impossible to say that one class of compounds is more toxic than another. The present data conform to this view. Some attention has been given to the herbicidal effect of inserting a double bond into a paraffin molecule. Havis (1950), working with a large group of pure hydrocarbons of various kinds, concluded that this increased toxicity only slightly. On the other hand, Leonard and Harris (1952) found that, with the exception of the pair hexene- 1 and $n$-hexane, the olefins were considerably more toxic than the paraffins when applied as spray to cotton hypocotyls. Why hexene and hexane should behave differently is not clear at present. Changes in physical properties due to the double bond doubtless have more influence on toxicity than any increased chemical reactivity. The toxicity of olefins is known to increase upon storage in the light, and this could be a factor, especially in chronic injury resulting from treatment with higher-boiling compounds.

The demonstrated injury resulting from reaction products of olefins and ozone (Haagen-Smit et al., 1952) has to do with a somewhat different problem. It is quite evident that rather small quantities of these ozonides can be toxic, but under the conditions of the present experiments it is not likely that they were present in sufficient amount to have contributed to acute injury.

Water Solubility. In homologous series of hydrocarbons it has been shown (Richet, 1893) that, within limits, toxicity is inversely correlated with water solubility, and this is demonstrated in the series benzene, toluene, xylene, mesitylene. That this relation fails however, when different types of hydrocarbon vapors are considered is indicated in the present work, where there is a positive correlation between these quantities, provided toxicity is considered as the reciprocal of minimum lethal concentration. As a further complication, in aqueous solution there is an inverse correlation of toxicity and solubility. This is why Ferguson (1939) concluded that toxicity ratings based on concentration can be misleading. It is clear that in comparing toxicities the diluent must be specified.

Oil Solubility. Oil solubility of hydrocarbons (see table 7) seems generally correlated in a direct way with toxicity, especially when vegetable oils are used as solvents. 
Distribution Coefficients. Of the distribution coefficients the oil/air values seem to agree better with the order of toxicity in the vapor tests than the water/air or the oil/water values (table 7). This conforms to the idea that it is really the air-lipid distribution that determines the equilibrium toxic concentration in the ectoplast. When plants are treated with aqueous solutions the oil/water values are important.

\section{Activity versus Concentration}

It was mentioned above that on a concentration basis the toxicity of the series benzene, cyclohexene, cyclohexane, hexane, hexene, decreases when applied as vapor diluted with air, but increases when water is the diluent. On this basis, in air hexene is about one third as toxic as benzene, but in water it is about eleven times as toxic. A similar situation reported by Fühner (1923) is that on an equimolar basis chloroform in the gaseous phase is more toxic than carbontetrachloride, while the reverse is true in water. Meyer and Hemmi (1935) interpret this as due to differing solubility relations and distribution constants, and this will also explain the benzenehexene situation.

Ivens (1952) found that in a homologous series of hydrocarbons, as the vapor pressure decreased a point was reached where the vapors became nontoxic. This he termed the "cut-off" point in the series. In our terminology, this result is due to a low value of the $\frac{\text { cell lipid }}{\text { air }}$ distribution of hydrocarbon.

Ferguson (1939) suggested that the effectiveness of toxicants which act essentially in a biophysical manner is best compared by the value of the chemical potential in the external phase, because by thermodynamic consideration it is known that the potential in the cellular phase involved (point of action) will be the same. The activity function of G. N. Lewis is used as an expression of chemical potential. The hypothesis seems generally to be supported by the work of several investigators (Hurst, 1943; Burtt, 1945; Gavaudan, Dodé, and Poussel, 1946; Brink and Posternak, 1948; Webb, 1949 ; Ivens, 1952). Much of this work has dealt with the effect of toxic vapors on insects. The principal also finds support in certain of the present data.

In the gaseous state, the degree of saturation (relative saturation) is equal to the thermodynamic activity of the toxic vapor. Ferguson and Pirie (1948) found that whereas the relative saturation of the physically acting toxicants lay between 0.1 and 1.0 for grain weevils, concentrations varied within wide limits. For example, at equal thermodynamic activity, ethyl chloride is shown to be about 200 times as concentrated as $s$-tetra-chloroethane.

Dalton's law of partial pressure implies that a gas will diffuse into a space already occupied by another gas as if the second gas were not there. Consequently the air saturation values at $25^{\circ} \mathrm{C}$ can be calculated from the relation $n=\frac{P V}{R T}$. And from the minimum lethal amount of hydrocarbon vapor known to be present (table 3 ) the relative saturation of air can be determined (table 9). There is a general increase in saturation with increase in minimum lethal concentration-this in contrast to the benzene, toluene, 
xylene, mesitylene series (Ferguson and Pirie, 1948; Currier, 1951), where the relative saturation increases as the minimum lethal concentration decreases. The explanation for these differences probably lies in a decreasing lipid solubility for the series benzene, cyclohexene, cyclohexane, hexane,

TABLE 9

RELATIVE SATURATION IN AIR AND IN WATER OF HYDROCARBONS AT MINIMUM LETHAL CONCENTRATION

Based on data in tables 3 and 6

\begin{tabular}{|c|c|c|c|c|}
\hline Hydrocarbon & \multicolumn{2}{|c|}{ Relative saturation in air } & \multicolumn{2}{|c|}{$\begin{array}{l}\text { Relative saturation in } \\
\text { aqueous solution }\end{array}$} \\
\hline Benzene. . & 0.51 & 0.77 & 0.35 & 0.60 \\
\hline Cyclohexane... & .73 & 1.0 & 0.70 & $>1.0$ \\
\hline Hexene....... & .77 & 0.98 & 0.79 & $>1.0$ \\
\hline Hexane......... & 0.78 & 0.96 & $>1.0$ & $>1.0$ \\
\hline
\end{tabular}

TABLE 10

THEORETICAL CONCENTRATION, IN MOLES PER LITER, OF HYDROCARBON IN CELL LIPID, WHERE EXTERNAL CONCENTRATION IS LETHAL MINIMUM Calculated by use of oil/air and oil/water distribution constants, with oil models as indicated

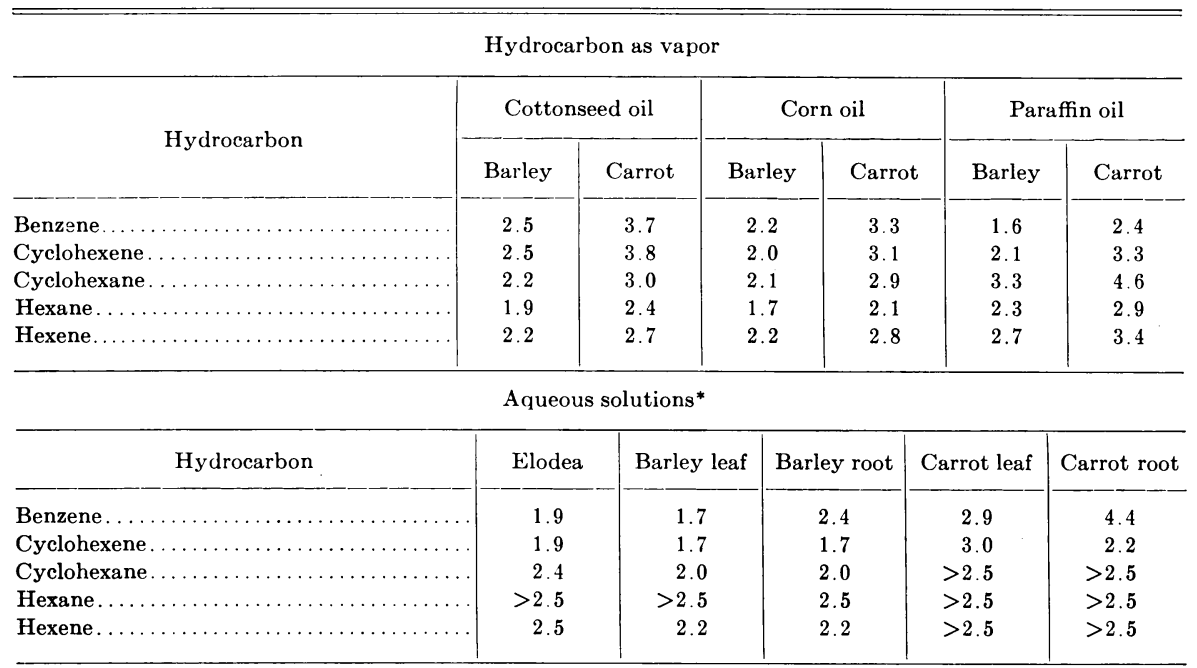

* Cottonseed-oil values employed.

hexene, and a markedly decreasing vapor pressure for the series benzene, toluene, xylene, mesitylene.

Ferguson's Principle predicts that substances which act in a physical manner, when present at the same degree of saturation in a diluent, have 
the same degree of toxicity. In addition to hydrocarbon vapors, there is supporting evidence where the diluent is water. For example, in table 5 it can be seen that benzene and cyclohexene will kill Anacharis at about the same relative saturation, whereas the concentration of the first is roughly six times that of the second. From a practical viewpoint-for example in water-weed control-it should be of interest to seek toxic compounds of low solubility, but where the minimum lethal concentration is below 100 per cent saturation. That there is a limit as to how low the solubility can be is evidenced by the fact that saturated hexane-in-water solutions are essentially nonlethal, judging from the results of experiments reported in a previous section.

Relative saturation values in water at lethal minimum concentrations are included in table 9. Comparative values are somewhat less for benzene and cyclohexene than in air; otherwise there is fair agreement.

\section{Theoretical Concentration in Cell Lipid}

Using cottonseed and corn oils as models, the theoretical concentration of hydrocarbon in cell lipid can be calculated by means of distribution coefficients. The values obtained with respect to hydrocarbon vapor and oil/air coefficients suggest rather constant values of about 2 molar for barley and 3 molar for carrot tissue (table 10, upper section), indicating that there is no great difference in the absolute toxicity of the five species of hydrocarbons. That is, apparent differences in toxicity are due to physical factors involved in movement of the molecules to the site of action and their retention there. Such calculations were made by Meyer and Hemmi (1935) for a series of animal narcotics and they also arrived at rather constant values.

Where the hydrocarbons are dissolved in water, and where oil/water coefficients are used in similar calculations, one obtains similar values (table 10 , lower section).

The data reveal that differences among plants must be more important than differences in structure of hydrocarbons. Some unique variation in the nature of the carrot ectoplast may explain the relative resistance of this plant and its relatives to weed oils, as compared with other plants. What this difference might be is the subject for continuing study.

\section{ACKNOWLEDGMENTS}

The writers are indebted to Mr. H. R. Drever for technical assistance in conducting the greenhouse experiments. 
ALBERT, A.

\section{LITERATURE CITED}

1951. Selective toxicity; with special reference to chemotherapy. $228 \mathrm{p}$. Methuen and Co., Ltd., London, England.

Brink, F., and J. M. Posternak

1948. Thermodynamic analysis of the relative effectiveness of narcotics. Jour. Cell. and Compar. Physiol. 32: 211-33.

BURTT, E. T.

1945. The mode of action of sheep dips. Ann. Appl. Biol. 32: 247-60.

BUTLER, T. C.

1950. Theories of general anesthesia. Pharmacol. Rev. 2: 121-60. Issued as: Jour. Pharmacol. and Exp. Therapeutics 98 (no. 4, pt. 2) : 121-60.

Craft's, A. S.

1948. A theory of herbicidal action. Science 108: 85-86.

Crafts, A. S., H. B. Currier, and O. A. Leonard

1951. Toxicity of herbicidal oils. Proc. Third World Petroleum Congress, The Hague, Netherlands. p. 198-203.

Crafts, A. S. and H. G. Reiber

1948. Herbicidal properties of oils. Hilgardia 18: 77-156.

Currier, H. B.

1949. Responses of plant cells to herbicides. Plant Physiol. 24: 601-9.

1951. Herbicidal properties of benzene and certain methyl derivatives. Hilgardia 20 : $383-406$.

Dallyn, S. L., and R. D. Sweet

1951. Theories on the herbicidal action of petroleum hydrocarbons. Amer. Soc. Hort. Sei. Proc. 57: 347-54.

DaNielli, J. F.

1950. Cell physiology and pharmacology. viii +156 p. Elsevier Publ. Co., Inc., New York, N.Y.

Davson, H., and J. F. DANIELli

1952. The permeability of natural membranes. $2 d$ ed., xii +365 p. University Press, Cambridge, England.

DeOng, E. R., H. Knight, and J. C. Chamberlin

1927. A preliminary study of petroleum oil as an insecticide for citrus trees. Hilgardia 2: $351-84$.

Ferguson, J.

1939. The use of ehemical potentials as indices of toxicity. Roy. Soc. London, Proc., Ser. B. 127: 387-403.

Ferguson, J., and H. Pirie

1948. The toxicity of vapours to the grain weevil. Ann. Appl. Biol. 35: 532-50.

FüHNER, H.

1923. Die Wirkungsstärke von Chloroform und Tetrachlorkohlenstoff. Arch. f. Exper. Path. u. Pharmakol. 97: 86-112.

Gavaudan, P., M. Dodé, and H. Poussel

1946. Contribution à l'étude du mecanisme de la narcose par les narcotiques indifférents.

Rec. des Trav. Toxicol. et Pharacodyn. Cell. (Trav. Sci. Sta. Essais Bouchet)

2: 1-36. Abstracted in: Biol. Abs. 22: 236 (Abs. no. 2696). 1948.

HaAgen-Smit, A. J., E. F. DARley, M. Zaitlen, H. Hull, and W. Noble

1952. Investigation on injury to plants from air pollution in the Los Angeles area. Plant Physiol. 27: 18-34.

Handbook of Chemistry and Physics

1950-51. Handbook of chemistry and physics. $32 d$ ed., $x x+2879$ p. Chemical Rubber Publ. Co., Cleveland, Ohio.

Havis, J. R.

1950. Herbicidal properties of petroleum hydrocarbons. New York (Cornell) Agr. Exp. Sta. Mem. 298: 1-20.

HuRst, $\mathrm{H}$.

1943. Principles of insecticidal action as a guide to drug reactivity-phase relationships. Faraday Soc. Trans. 39 : 390-411. 
Ivens, G. W.

1952. The phytotoxicity of mineral oils and hydrocarbons. Ann. Appl. Biol. 39: 418-22.

Jensen, C. O., W. Sacks, and F. A. Baldauski

1951. The reduction of triphenyltetrazolium chloride by dehydrogenases of corn embryos. Science 113: $65-66$.

Johnson, C. M., and W. M. Hoskins

1952. The relation of acids and peroxides in spray oils to the respiration of sprayed bean leaves and the development of injury. Plant Physiol. 27: 507-25.

LeONARD, O. A., and V. C. Harris

1952. The effect of aliphatic hydrocarbons on the hypocotyls of cotton and soybeans and on the shoots of nut grass, Johnson grass and other weeds by the directional spray technique. Weeds 1: 256-73.

MEYer, K., and H. Hemmi

1935. Beiträge zur Theorie der Narkose. III. Biochem. Ztschr. 277: 39-71.

Minshall, W. H., and V. A. Helson

1949. The herbicidal action of oils. Amer. Soc. Hort. Sci. Proc. 53: 294-98.

Overton, E.

1901. Studien über die Narkose zugleich ein Beitrag zur allgemeinen Pharmakologie. $\mathrm{x}+195$ p. Gustav Fischer, Jena.

Phillips Petroleum Company

1949. Phillips hydrocarbons. 3d ed. 160 p. Bartlesville, Oklahoma.

Richet, CharLes

1893. Note sur le rapport entre la toxicité et les propriétés physiques des corps. Soc. de Biol. [Paris] Compt. Rend. 45: 775-76.

Sмiтh, F. E.

1951. Tetrazolium salt. Science 113: 751-54.

Timmermans, J.

1950. Physico-chemical constants of pure organic compounds. xiii +639 p. Elsevier Publ. Co., Ine., New York, N.Y.

TUCKeR, R. P.

1936. Oil sprays. Chemical properties of petroleum oil unsaturates causing injury to foliage. Indus. and Engin. Chem. 28: 458-61.

van Overbeek, J., and Rene BlondeAu

1953. Mode of action of phytotoxic oils. First National Weed Control Conf., Kansas City, Missouri, December, 1953. 11 p. (Mimeo.) To appear also in: Weeds.

VAN Slyke, D. D.

1939. Determination of solubilities of gases in liquids with use of the Van Slyke-Neill manometric apparatus for both saturation and analysis. Jour. Biol. Chem. 130: $545-54$.

WEBB, J. E.

1949. The permeability of insect cuticle. Soc. Exp. Biol. [Gt. Brit.] Symposia 3: 143-63.

Wedding, R. T., L. A. RIEHL, and W. A. Rhoads

1952. Effect of petroleum oil spray on photosynthesis and respiration in citrus leaves. Plant Physiol. 27: 269-78. 

The journal Hilgardia is published at irregular intervals, in volumes of about 600 pages. The number of issues per volume varies.

Subscriptions are not sold. The periodical is sent as published only to libraries, or to institutions in foreign countries having publications to offer in exchange.

You may obtain a single copy of any issue free, as long as the supply lasts; please request by volume and issue number from:
Agricultural Publications
Room 22, Giannini Hall
College of Agriculture
Berkeley 4, California

The limit to nonresidents of California is 10 separate issues on a single order. A list of the issues still available will be sent on request.

In order that the information in our publications may be more intelligible it is sometimes necessary to use trade names of products or equipment rather than complicated descriptive or chemical identifications. In so doing it is unavoidable in some cases that similar products which are on the market under other trade names may not be cited. No endorsement of named products is intended nor is criticism implied of similar products which are not mentioned. 